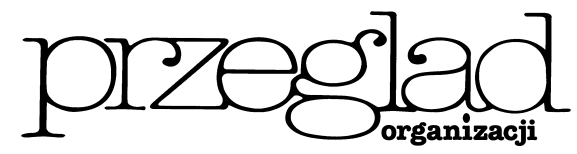

\title{
Zarządzanie marketingowe w świetle idei postmodernistycznych

\section{Wprowadzenie}

M arketing wydaje się leżeć w centrum instrumentalnego dyskursu nauk o zarządzaniu. Niewątpliwie dominujący obraz zarządzania marketingowego sugeruje racjonalistyczny obraz podmiotu gospodarczego działającego na rynku, dążącego do osiagnnięcia sukcesu poprzez systematyczne poznawanie oraz planowe kształtowanie i zaspokajanie potrzeb potencjalnych klientów. A jednak do współczesnej teorii i praktyki marketingu pasują również relatywistyczne idee postmodernizmu. Proponuję przyjrzeć się podstawowym założeniom rodzącego się nurtu marketingu postmodernistycznego.

Postmodernizm to szeroka i wieloznaczna formacja intelektualna, która swoim zasięgiem obejmuje wiele dziedzin sztuki i nauki. Zainteresowanie inspiracjami postmodernistycznymi w naukach o zarządzaniu było nikłe aż do lat 80 . ubiegłego stulecia, kiedy to rozwinęło się konstruktywistyczne i kognitywne rozumienie organizacji ${ }^{1}$.

Podejście postmodernistyczne zaczęło rozpowszechniać się w marketingu na przełomie lat 80. i 90. pod wpływem idei społeczeństwa sieciowego i konsumeryzmu. Wśród najważniejszych autorów posługujących się perspektywą postmodernistyczną w marketingu wymienić można: S. Browna ${ }^{2}$, F.A. Firata, J. Clifforda, I. Shultza ${ }^{3}$, A. Venkatesha, M.B. Holbro$\mathrm{oka}^{4)}$ oraz J. Oglivy ${ }^{5}$. Mimo programowej wieloznaczności wyróżnić można kilka cech postmodernizmu, które zostaną odniesione do marketingu ${ }^{6}$.

\section{Relatywizm epistemologiczny i kulturowy}

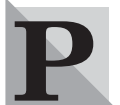

ostmoderniści kwestionują możliwość dotarcia do obiektywnej prawdy; prawda jest skutkiem społecznej mediacji i jest raczej konstruowana, niż odnajdywana. R. Rorty podważa sens rozwoju epistemologii, nauki bazującej na założeniu poznawania jako odzwierciedlania rzeczywistości ${ }^{77}$. Porzucona zostaje zatem korespondencyjna koncepcja prawdy, obiektywizm i uniwersalne kryteria racjonalności ${ }^{8}$.

Do marketingu doskonale pasuje postmodernistyczna antyepistemologia. Nie jest to nauka odzwierciedlająca obiektywnie istniejący świat, lecz dziedzina działalności społecznej, która aktywnie tworzy rzeczywistość rynkowa. Teorie i metodyki badań wypracowane przez marketing mają charakter pragmatyczny i lokalny, a nie stanowią odbicia uniwersalnych prawideł. Właściwie można byłoby powiedzieć za A. Venkateshem, że marketing zawsze był postmodernistyczny, choć nie zdawał sobie z tego sprawy ${ }^{9}$. Konsument, marka, tożsamość organizacji, orientacja marketingowa, wizerunek firmy, a nawet strategia marketingowa to nie są kategorie obiektywne, lecz konstruowane jako społeczne konsensusy, porządkujące i zmieniające nasz świat. Powstają one na zasadzie rozwiązań kulturowych, są bytami zbiorowymi, a więc godzą oraz łączą utrwalone historycznie wartości i interesy różnych stron.

Zgodnie z założeniami postmodernizmu marketing, jak i nauka w ogóle, jest działalnością opartą na wartościach, a prawda staje się jedynie narracją ${ }^{20}$. Firma i rynek to kategorie umowne, a więc wieloznaczne i interpretowane na wiele sposobów, których nie powinno się rozpatrywać jako Wittgensteinowskie „gry językowe”. We współczesnym dyskursie zarządzania przejawem tego myślenia może być wykorzystywanie metafor ${ }^{11)}$, paradoksów ${ }^{12)}$ czy archetypów ${ }^{13)}$ jako narzędzi działania.

Głęboką konsekwencją przyjęcia stanowiska postmodernistycznego jest założenie relatywizmu kulturowego, zgodnie z którym różne kultury tworzą odrębne światy sensu. Rodzi to konsekwencję w postaci niewspółmierności dyskursów wywodzących się z różnych kultur. Nieprzekładalność i hermetyzm dyskursów uniemożliwiają pełnię komunikacji i negują klasyczny model komunikowania jako transferu danych.

Marketing w coraz większym stopniu orientuje się na uwzględnianie wpływów kultury i odchodzenie od rozwiązań uniwersalistycznych. Nie jest to może orientacja skrajnego relatywizmu kulturowego zakładająca nieprzekładalność dyskursów, lecz umiarkowany etnorelatywizm. Marketing nie oferuje rozwiązań i metod, które są użyteczne, niezależnie od warunków funkcjonowania społeczeństwa. Przydatność poszczególnych narzędzi i koncepcji marketingu, takich jak: strategie, badania rynkowe, orientacja marketingowa czy marketing-mix jest różna w zależności od kultu$\mathrm{ry}^{14}$. J.-C. Usunier wyróżnia kilka obszarów marketingu kulturowego, które różnicują społeczeństwa, a co zatem idzie efektywność technik marketingu ${ }^{15)}$ :

- wpływ kultury na zachowania nabywców,

- międzykulturowe badania marketingowe,

- międzykulturowe strategie,

- międzykulturowa komunikacja i zarządzanie znaczeniami,

- marketing-mix w kontekście kultury.

Myślenie postmodernistyczne ma charakter bardziej radykalny od etnorelatywizmu. Relatywizm kulturowy może prowadzić do wniosku, że marketing, jako wytwór konkretnej kultury (zachodniej), głęboko tkwi w jej systemie wartości i nie da się zastosować $\mathrm{w}$ wielu innych kontekstach kulturowych. W tym znaczeniu marketing to również narzędzie kulturowej „kolonizacji”, a później naukowej racjonalizacji tego 
procesu. Narzucanie myślenia marketingowego dokonuje się poprzez mechanizm imperializmu kulturowego, który nie ma żadnego poznawczego uzasadnienia, lecz stanowi konsekwencje propagowania przez środki komunikacji zachodniego systemu wartości. Zatem dzięki oddziaływaniu mediów upowszechniają się pomiędzy różnymi kulturami kategorie: konsumenta, marki czy reklamy.

\section{Komunikacja w sieci znaczeń symbolicznych}

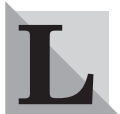

udzie uwikłani są w sieci znaczeń. J. Derrida lansuje propozycje tekstualizmu ${ }^{16)}$. Świat symboliczny opiera się na zmiennych i subiektywnych narracjach, które kształtują się w indeterministycznych „grach językowych” w kulturze. Granice naszego języka są zatem granicami naszego świata ${ }^{17}$. Jak wskazał J. Baudrillard w postmodernizmie następuje oderwanie symbolu od desygnatu i przejście do znaczeń konstruowanych w procesie kulturowym. Produkty, potrzeby klientów, wizje konsumenta i mody zatracają aspekty reprezentacji, staja się kreacją, a później symulacją rzeczywistości ${ }^{18)}$.

A. Venkatesh wskazuje, że współcześnie mamy do czynienia z „ekonomią znaków”, która przybiera charakter postmaterialny. Konsumenci kupują marki i znaczenia, które odczytują subiektywnie posługując się kulturowymi interpretacjami ${ }^{19)}$. Komunikacja marketingowa odbywa się przede wszystkim w świecie symbolicznym. Dominacja usług w gospodarce, wzrost roli marki i mody, to tylko niektóre przejawy funkcjonowania marketingu jako komunikacji symbolicznej. Marketing staje się systemem produkcji znaczeń symbolicznych związanych z konsumpcją, które są lansowane społecznie. Modernistyczna ekonomia przyjmowała domyślne założenie, że rozwojem ekonomicznym kierują mierzalne i uchwytne czynniki, a nie tak efemeryczna kategoria, jak symbole czy znaczenia. A jednak subiektywnie interpretowane, kulturowe i zmienne marki opanowały świat, negując modernistyczny dogmat. Przejawem rozwoju symbolicznego marketingu może być wzrost znaczenia mody, ironii, buntu i kontrkultury w kreowaniu i lansowaniu marek ${ }^{20)}$. Postmodernistyczny „paradygmat” reklamy odrzuca klasyczny model transmisji informacji i wywierania wpływu na potencjalnych klientów, a koncentruje się jedynie na symbolu i jego odczytaniu.

\section{Subiektywizm i partykularyzm}

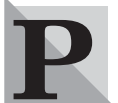

ostmodernizm jest orientacja subiektywistyczną. Gry kulturowe i językowe są niewspółmierne i tworzą zamknięte pod względem sensu konstrukty, które są interpretowane wyłącznie subiektywnie. W znaczeniu postmodernistycznym nie ma uniwersalnych i obiektywnych wzorców prawdy i sensu. Są one owocem kultury, która z kolei podlega subiektywnemu odczytaniu. Postmodernizm zrywa z uniwersalistycznym rozumieniem idei i ról społecznych. Dobro, piękno i prawda to tylko narracje przewijające się w dziejach ludzkości ${ }^{21)}$. Role kobiece i męskie, przywódców i zwolenników, producentów i konsumentów są kulturowymi etykietami, które mogą być w dowolny sposób kształtowane w dyskursie społecznym.

Subiektywizm i partykularyzm w marketingu oznacza przyjęcie założeń pełnej, kulturowej elastycz- ności konsumenta. Stanowi on rodzaj „kulturowej plasteliny", która jest kształtowana w procesie komunikacji. Komunikacja marketingowa jest zatem w stanie stymulować mody w każdej sferze społecznej. Modę na muzykę, jedzenie, ubranie, a nawet na polityka.

Marka i tworzone przez marketing znaczenia symboliczne zyskują aspekty przemocy symbolicznej22). Narzucają kulturom i jej uczestnikom „skrypty komunikacyjne" i stereotypy. Gotowe sposoby rozumienia rzeczywistości społecznej, które pozwalają na unikanie postawy refleksyjnej i otwartej na odmienność.

Postmodernistyczny marketing nie zakłada, że twórcy komunikacji marketingowej pełnią rolę demiurga. Mogą oni wpływać na kierunki rozwoju dyskursu, ale nie mogą go w pełni kontrolować. Wewnątrz kultury mogą przyjąć się pewne motywy, inne zaś nie zyskać na znaczeniu. Twórcy komunikacji marketingowej lansujący określoną modę starają się jak najczęściej podsuwać odbiorcom wzorce i obserwować, $\mathrm{w}$ jakim stopniu zostały one podchwycone. Oczywiście z góry wiadomo, że ze względu na efemeryczność konsumenta nie będą one trwałe.

\section{Hiperrzeczywistość}

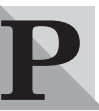

ostmodernizm odrzuca korespondencyjną koncepcję prawdy. Mamy do czynienia z wielością rzeczywistości i ich subiektywną interpretacją. J. Baudrillard posługuje się określeniem „symulakra" dla opisu procesu konstruowania świata przeżywanego przez człowieka ${ }^{23)}$.

Współczesne badania nad mediami, komunikacją masową i cyberprzestrzenią zbliżają się do postmodernistycznych idei hiperrzeczywistości. Semiotyka R. Barthesa i badania ideologicznego wpływu mediów prowadzone przez S. Halla wskazują, że komunikacja społeczna może być interpretowana jako proces produkcji znaczeń kulturowych, które współtworzą rzeczywistość członków społeczeństwa ${ }^{24)}$. Powstanie cyperprzestrzeni jest drugim obok wpływu massmediów, współczesnym ucieleśnieniem idei hiperrzeczywistości. D. Peppers i M. Rogers mówią o zmianie paradygmatu marketingowego towarzyszącego rozwojowi internetu, który wskazuje na przejście od komunikacji jednokanałowej do wielokanałowej i zindywidualizowanej komunikacji interaktywnej25). Cyberprzestrzeń opisywana jest za pomocą metafor porównujących ją do przestrzeni fizycznej, do książek, do filmów. Jednak jest ona jakościowo odmienna od znanej nam wcześniej rzeczywistości codziennej. W cyberprzestrzeni zatarciu ulega tożsamość wędrowców, którzy pozostaja zanurzeni w bezgranicznej symulacji istniejącej w ich umysłach i w procesie komunikacji. Z punktu widzenia zarządzania marketingowego powstaje nowe wyzwanie w postaci stworzenia cybermarketingu ${ }^{26}$. Nie chodzi tutaj wyłącznie o konwencjonalne wykorzystanie nowych narzędzi promocji i kanałów dystrybucji, ale o zmianę perspektywy poznawczej konsumenta i producenta. Komunikacja $\mathrm{z}$ konsumentem o rozmytej lub zakamuflowanej tożsamości w sieci zatraca charakter wypracowanego przez marketing modelu komunikacji masowej z docelowym, modelowym segmentem klientów. Efemeryczność hiperrzeczywistości zmusza do ogromnej elastyczności tworzonych strategii marketingowych, narzędzi promocji-mix oraz kanałów dystrybucji. Produkty i usługi funkcjonujące w sieci zyskują nowe znaczenia symboliczne. Cy- 
berprzestrzeń stanowi odzwierciedlenie idei fragmentacji podmiotu i orientacji konsumpcyjnej. Z jednej strony chodzi o wielość tożsamości konsumenta, zaś z drugiej, o natychmiastową dostępność informacji i rozrywki w sieci, które pozwalają niezwłocznie zaspokajać zachcianki postmodernistycznego nabywcy. Sądzę zatem, że trzeba zgodzić się ze stwierdzeniem D.L. Hoffmana, że internet jest „najważniejszym wynalazkiem od czasu odkrycia druku" i niesie ze sobą potencjał zmian „nie tylko biznesowych, ale dotyczących istoty bycia człowiekiem w społeczeństwie"27).

\section{Fragmentacja świata i podmiotu}

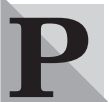

ostmodernistyczna wizja świata jest skrajnie pluralistyczna. Wszystkie kryteria podziału grup i ludzi są umowne, zatem potencjalnie możliwa jest pełna różnorodność kulturowa. Przedstawienie rzeczywistości można odnieść raczej do metafory malarstwa impresjonistycznego, ekspresjonistycznego lub surrealistycznego niż naturalistycznego. Różne grupy, potrzeby, dyskursy żyją w odrębnych światach. Nie ma jednego klucza do zrozumienia i poznania rzeczywistości. Fragmentacji podlega zatem świat i jaźń człowieka.

W marketingu owa fragmentacja przejawia się wzrastającą segmentacją i dyferencjacją produktów oraz dekonstrukcją tożsamości. Konsumenci dzieleni są na potencjalnie coraz mniejsze grupy, którym dostarczany jest symbolicznie zróżnicowany produkt. Ma to tworzyć wrażenie odejścia od standaryzacji w kierunku indywidualizacji.

Modernistyczna wizja marketingu zakładała docieranie do klienta, który posiada względnie stabilną strukturę ,jaźni”, a więc wyklarowane, choć nie zawsze w pełni uświadamiane potrzeby oraz spójny system znaczeń. Postmodernizm wskazuje na zdestabilizowaną tożsamość, która wiąże się ze zmiennymi, chwilowymi wyborami konsumenckimi trudnymi do osadzenia w trwałej strukturze potrzeb. Postmodernistyczny klient „ulega zachciankom”, daje się ponieść modzie, zmienia swoje decyzje i oczekiwania w nieprzewidywalny sposób.

\section{Konsumeryzm}

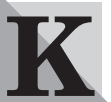

onsumpcja staje się formą religii i ideologii postmodernistycznej. Nie chodzi już wyłącznie o przedłużenie tendencji do akumulacji, nabywania coraz większej liczby dóbr materialnych, ale o zmianę stylu życia, w której konsumpcja warunkuje egzystencję $e^{28)}$. W stadium postmaterialnym konsumpcja w małym stopniu zaspokaja fundamentalne potrzeby fizjologii czy bezpieczeństwa, lecz sama staje się zinternalizowną potrzebą. Produkt zyskuje znaczenie nadawania tożsamości jednostek i grup. Ponieważ jednak konsumeryzm zakłada wzrost tempa konsumpcji, to sama tożsamość staje się płynna i zmienna. Produkt i jego konsumowanie staje się metafora rdzeniową postindustrialnego społeczeństwa. Każdy rodzaj aktywności ludzkiej - od sztuki, przez politykę i edukację aż do życia rodzinnego w coraz większym stopniu odczytywany jest w transakcyjnych i konsumpcyjnych kategoriach.

Charakterystyczne jest dokonujące się w wielu krajach rozwiniętych uzależnienie całego systemu gospodarczego od konsumpcji. Marketing lansuje orientację konsumpcyjną zamiast produkcyjnej odwołując się do różnych motywacji (konsumpcja jako wzór, patriotyzm, moda, styl życia). Cały system finansowania i dystrybucji sprzyja napędzaniu konsumpcji. Odbywa się to na przykład poprzez: wzrastającą specjalizację działalności podmiotów gospodarczych, wzmacnianie siły nabywczej konsumentów poprzez system kredytowania oraz zintensyfikowaną dystrybucję i promocję. Konsumeryzm jest owocem marketingu i pozwala na jego dalszy rozwój. Przykładem tego sprzężenia zwrotnego może być pojawianie się coraz bardziej wyrafinowanych uczestniczacych metod badań konsumentów oraz partycypacyjnych narzędzi promocji („uliczni promotorzy”) ${ }^{29)}$. W wydaniu postmodernistycznym konsumeryzm odznacza się efemerycznością i fragmentaryzacją tożsamości konsumenta. Odrzuca się analityczne narzędzia badań rynkowych i procesy planowania strategii marketingowych na rzecz metafory rynku jako ,gry kulturowej”. Utrzymywanie się na fali konkurencyjnej jest coraz częściej owocem innowacyjności i elastyczności pozwalającej na stałe rozbudzanie „zachcianek” konsumentów.

\section{Posttayloryzm i postfordyzm}

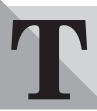

ayloryzm i fordyzm to etykietki modernizacji industrializacyjnej społeczeństwa masowego. Zręby tej koncepcji opierają się na założeniach masowej produkcji wykorzystujacej ekonomię skali, która jest wsparta zuniformizowaną konsumpcją ${ }^{30}$. Tayloryzm i fordyzm wyrastały $z$ ducha neopozytywizmu i industrializacji. Naukowa organizacja pracy przejawiała się koniecznością deterministycznego podziału pracy na elementarne sekwencje poddane drobiazgowej kontroli kierownictwa. Marketing u swego zarania nawiązywał do tych założeń. Miał proponować planowe modele aktywności sprzedażowej, komunikacyjnej, dystrybucyjnej i cenowej przedsiębiorstwa działającego w warunkach masowej produkcji dóbr. Podstawowy krąg idei strategii marketingowej, badań marketingowych i marketingu-mix bazował na deterministycznych założeniach.

Zmiany w kierunku gospodarki postindustrialnej doprowadziły do odejścia od paradygmatu Taylora-Forda w naukach o zarządzaniu. D. Bell pisząc o rodzeniu się społeczeństwa postindustrialnego trafnie dostrzegł transformację $\mathrm{w}$ kierunku podejścia informacyjnego, zorientowanego na działalność symboliczną - usługi i konsumpcję ${ }^{31}$. A. Toffler wśród znaczących trendów zmian współczesnego społeczeństwa wymienił:

- tworzenie się indeterministycznego społeczeństwa informacyjnego,

- wzrost tempa życia i presji zmian,

- konsumeryzm w „społeczeństwie wyrzucajacym rzeczy",

- wzrost różnorodności i możliwości wyborów jednostkowych i zbiorowych ${ }^{32)}$.

Wspomniane procesy prowadzą do zupełnie nowej postmodernistycznej orientacji wobec procesów zarządzania nazywaną posttayloryzmem lub postfordyzmem. Odznacza się ona: dominacją usług w gospodarce, elastyczną produkcją i dystrybucją, decentralizacją zarządu oraz orientacją na wiedzę.

Nowa orientacja w naukach o zarządzaniu niesie również znaczące konsekwencje dla zarządzania marketingowego. Według niektórych badaczy organizacje przyszłości będą: wielokulturowe i pluralistyczne, sie- 
ciowe, zdecentralizowane i heterarchiczne oraz bazujące na dobrach symbolicznych ${ }^{33)}$. Organizacje działające $\mathrm{w}$ społeczeństwie informacyjnym będą opierały się na samokierujących, elastycznych zespołach pracowniczych. Działania marketingowe powinny stać się przedmiotem zainteresowania większości pracowników, a nie wyłącznie wyspecjalizowanych komórek. W tym celu potrzebne są wielokierunkowe kompetencje pracowników, którzy potrafią szybko dostosować się do zmiennych wymagań. Marketing wielokulturowy musi uwzględniać fundamentalne znaczenie różnic językowych i kulturowych tworzac wielowymiarowe, sieciowe i interaktywne więzi z klientami. Zatem prawdopodobny wydaje się rozwój metod marketingu partnerskiego i relacyjnego, które będą dostosowane do lokalnego kontekstu kulturowego. Założenie społecznego konstrukcjonizmu oraz znaczenie dóbr symbolicznych skłania marketingowców do koncentracji na kreowaniu i lansowaniu znaczeń, które mają szansę wejść do dyskursu kulturowego. Rzeczywistość jest tworzona przez komunikację. Zatem rozwój komunikacji internetowej, telewizji interaktywnej, telefonii i wideofonii wzmacnia prymat tworzonego symbolu nad aspektami materialnymi świata.

\section{Kontekst władzy}

W ładza jest jednym z kluczowych wątków postmodernizmu. Wśród najważniejszych teoretyków tego nurtu zajmujących się problematyka władzy wskazać można: M. Foucault, Z. Bauma- na, E. Canettiego oraz R. Rorty'ego ${ }^{34)}$. M. Foucault powiązał problematykę poznania i wiedzy z zagadnieniem panowania. Władza krąży, funkcjonuje wyłącznie w formie łańcucha. Władzy nie można posiadać, ale jest ona wykorzystywana i sprawowana przez organizację podobną do sieci. Między jej nićmi cyrkulują zarówno jednostki, jak i grupy społeczne. Zgodnie z tym punktem widzenia jednostki są wehikułami władzy, a nie tylko miejscami jej stosowania. M. Foucault uważał, że władza zawsze wiąże się z wiedzą, bowiem panując, kreujemy prawdę. Nie można sprawować władzy inaczej jak tylko przez produkcję prawdy. Każde społeczeństwo, każda organizacja i każdy lider tworzą za pośrednictwem władzy swój „reżim prawdy", czyli mechanizmy umożliwiające odróżnianie twierdzeń prawdziwych i akceptowalnych od fałszywych, a więc odrzucanych ${ }^{35)}$.

Problematyka władzy jest sercem zarządzania i często utajonym kluczem pozwalającym na interpretację działań organizacji i ludzi w organizacji. Motyw wiedzy-władzy pojawia się również w zarządzaniu. G. Morgan, A. Toffler zauważają silne związki pomiędzy wiedzą a władzą w organizacjach ${ }^{36}$. Władza jest niezbywalnym elementem relacji organizacyjnej, który konstytuuje istnienie samej organizacji. Jednak sprawowanie władzy może być kontrowersyjne etycznie, ponieważ zazwyczaj wiąże się ze stosowaniem przemocy. Współcześnie częściej „przemocy symbolicznej” niż przemocy fizycznej37).

W odniesieniu do marketingu wskazać można na wątek problemów etycznych tej dyscypliny. Kreowa-

Tab. Porównanie perspektywy modernistycznej i postmodernistycznej w marketingu

\begin{tabular}{|l|l|l|}
\hline \multicolumn{1}{|c|}{ Kryterium } & \multicolumn{1}{|c|}{ Perspektywa modernistyczna } & \multicolumn{1}{c|}{ Perspektywa postmodernistyczna } \\
\hline Produkt & Dominuje produkt materialny & Dominuje produkt symboliczny oraz usługi \\
\hline Promocja & Zorientowana na obiektywne cechy produktu & $\begin{array}{l}\text { Zorientowana symbolicznie na proces interpre- } \\
\text { tacji marki }\end{array}$ \\
\hline Cena & Efekt użyteczności produktu & Efekt interpretacji produktu \\
\hline Dystrybucja & Wyspecjalizowani pośrednicy & Wielokanałowa i uproszczona \\
\hline Personel & Specjaliści & Generaliści (multiskilled) \\
\hline Strategia marketingowa & Model planistyczny & Strategie emergentne \\
\hline Badania rynkowe & Dane obiektywne, reprezentatywne badania & $\begin{array}{l}\text { Dane subiektywne, interpretacje, badania } \\
\text { uczestniczące, ingerujące }\end{array}$ \\
\hline Motywy klientów & $\begin{array}{l}\text { Akumulacja dóbr, oszczędność, racjonalność za- } \\
\text { kupów }\end{array}$ & $\begin{array}{l}\text { Interakcja, zaspokajanie ,zachcianek” i potrzeb } \\
\text { symbolicznych, podążanie za modą }\end{array}$ \\
\hline Model komunikowania & $\begin{array}{l}\text { Nadawca - Kanał - Odbiorca } \\
\text { Liniowy }\end{array}$ & $\begin{array}{l}\text { Symbol - Interpretator } \\
\text { Synchroniczny }\end{array}$ \\
\hline Cele komunikowania & Informowanie i perswazja & $\begin{array}{l}\text { Wywieranie wpływu } \\
\text { Narracja i kontynuacja dyskursu }\end{array}$ \\
\hline Kanał komunikacji & $\begin{array}{l}\text { Jednokanałowy, prosty, jednokierunkowy, } \\
\text { masowy }\end{array}$ & $\begin{array}{l}\text { Interaktywny, złożony, sprzężenie zwrotne, } \\
\text { zindywidualizowany }\end{array}$ \\
\hline Środki komunikacji & Tekst i obraz & Hipertekst i interaktywny obraz \\
\hline Podmioty komunikacji & $\begin{array}{l}\text { Segmenty klientów o sprecyzowanych } \\
\text { potrzebach }\end{array}$ & $\begin{array}{l}\text { Jednostki o rozmytej tożsamości, podatne na } \\
\text { wpływy komunikacji }\end{array}$ \\
\hline Dominujące media & Massmedia (telewizja, prasa, radio) & $\begin{array}{l}\text { Media interaktywne (internet, telewizja interak- } \\
\text { tywna) }\end{array}$ \\
\hline Technologie komunikacji & Technologie przesyłania obrazu i dźwięku & Technologie sieciowe i komputerowe \\
\hline Zón
\end{tabular}

Źródło: opracowanie własne. 
nie znaczeń i dóbr symbolicznych, takich jak marki jest rodzajem „przemocy symbolicznej” uprawianej przez korporacje. Dysponując wpływem na kanały komunikacji można manipulować znaczeniami dla realizacji interesów ekonomicznych i politycznych. Marketing postmodernistyczny zakłada wrażliwość etyczną na wyrafinowane formy manipulacji marketingowej i obnaża socjotechniczne i psychomanipulacyjne podejście modernistycznego marketingu.

Analizując przedstawione zręby koncepcji marketingu postmodernistycznego trzeba zaznaczyć, że są one niejednorodne. Jednocześnie przynoszą zupełnie nowe wątki, które nie znalazły się w klasycznej teorii marketingu. Można zaproponować zestawienie marketingu modernistycznego z postmodernistycznym, zakładając oczywiście, że jest to rodzaj uproszczenia (tabela).

Próba prezentacji postmodernistycznej perspektywy w marketingu wskazuje na celowość poszukiwania takich inspiracji. Mimo niejednoznaczności, skrajnego relatywizmu, niejasności terminologii, krytyki racjonalizmu i programowej niespójności ${ }^{38)}$, postmodernizm wydaje się być źródłem wartościowych analiz krytycznych w zarządzaniu marketingiem. Pozwala odejść od zbyt wąskiego, instrumentalnego postrzegania marketingu w kierunku refleksyjnej i wrażliwej etycznie dyscypliny społecznej. Trafnie chwyta nowe wątki zmian społeczeństwa współczesnego, takie jak: konsumeryzm, ekonomia znaków czy wielokulturowość. Podnosi refleksje epistemologiczne prowadzące do odrzucenia dogmatów paradygmatu neopozytywistycznego w naukach o zarzadzaniu ${ }^{39)}$. Dlatego wydaje się, że transfer nowych motywów nurtu postmodernistycznego na grunt marketingu powinien przynieść owocne rezultaty, choć powinien być traktowany jako analizy krytyczne, a nie próba budowania nowego paradygmatu. W przyszłości postmodernistyczne kwestie, takie jak: kapitał symboliczny, zarządzanie znaczeniami, tożsamością i wizerunkiem oraz jakościowe badania konsumpcji i zachowań klientów mogą znaleźć się w centrum zainteresowań marketingu ${ }^{40)}$

dr hab. Łukasz Sutkowski profesor w Społecznej Wyższej Szkole Przedsiębiorczości i Zarządzania w Łodzi

\section{PRZYPISY}

1) P. COSSETTE, L'organisation. Une perspective cognitiviste, Les Presses de l'Universite Laval, Canada 2004.

2) S. BROWN, Postmodern Marketing, „European Journal of Marketing", nr 27 (4), 1993, s. 19-34.

3) A. FIRAT, A. FUAT, C.J. SHULTZ, From Segmentation to Fragmentation: Markets and Market Strategy in the Postmodern Era, „European Journal of Marketing”, nr 31 (3/4), 1997, s. 183-207; A. FIRAT, A. FUAT, A. VENKATESH, Postmodernity: The Age of Marketing, „International Journal of Research in Marketing” 1993, nr 10 s. $227-249$

4) HOLBROOK, B. MORRIS, The Three Faces of Elitism: Postmodernism, Political Correctness, and Popular Culture, „Journal of Macromarketing”, nr 15 (Fall), 1995, s. 128-63.

5) J. OGLIVY, The Postmodern Business, „Marketing and Research Today", nr 18 (1), 1990, s. 4-20.

6) Porównaj: A.VENKATESH, Postmodernism Perspectives for Macromarketing: An Inquiry into the Global Information and Sign Economy, „Journal of Macromarketing", vol. 19, nr 12, grudzień 1999 .

7) R. RORTY, Filozofia a zwierciadto natury, Aletheia, Warszawa 1985.

8) Tamże, s. 121-262.

9) Porównaj: A.VENKATESH, Postmodernism Perspectives for Macromarketing: An Inquiry into the Global Informa- tion and Sign Economy, „Journal of Macromarketing”, vol. 19, nr 12, grudzień 1999.

10) Tamże, s. 304

11) G. MORGAN, Obrazy organizacji, PWN, Warszawa 1997.

12) K. PERECHUDA, Metody zarzadzania przedsiębiorstwem, Wyd. Akademii Ekonomicznej, Wrocław 1999.

13) R. KRUPSKI, Archetypy organizacji, [w:] Zmiana warunkiem sukcesu. Opór wobec zmian. Szansa czy zagrożenie? red. J. SKALIK, Wyd. Akademii Ekonomicznej, Wrocław 2000

14) P. KOTLER, S. JATUSRIPITAK, S. MAESINCEE, Marketing narodów. Strategiczne podejście do budowania bogactwa narodowego, Wyd. PSB, Kraków 1999.

15) J.C. USUNIER, Marketing Across Cultures, Pearson Education Limited, Third edition, Edinburgh Gate 2000.

16) J. DERRIDA, red. P.KAMUF, A Derrida Reader: Between the Blinds, N.Y.Columbia University Press, New York 1991.

17) L. WITTGENSTEIN, Tractatus logico-philosophicus, teza 5.6, PWN, Warszawa, 2002, s. 64.

18) J. BAUDRILLARD, For a Critique of the Political Economy of the Sign, MO: Telos, St. Louis 1981.

19) A. VENKATESH, Postmodernism Perspectives for Macromarketing: An Inquiry into the Global Information and Sign Economy, „Journal of Macromarketing”, vol. 19, nr 12, grudzień 1999.

20) N. KLEIN, No Logo, Świat Literacki, Izabelin 2004, s. $21-80$.

21) J.F. LYOTARD, Kondycja ponowoczesna. Raport o stanie wiedzy, Fundacja Altheia, Warszawa 1997.

22) P. BOURDIEU, Espace social et pouvoir symbolique, [w:] «Choses dites», Minuit, Paris 1987.

23) J. BAUDRILLARD, Symulacra and Simulation, University of Michigan Press, Ann Arbor 1994.

24) S. HALL, Representation: Cultural Representations and Signifying Practices, Sage, London 1997.

25) D. PEPPERS, M. ROGERS, The One-To-One Future, Judy Piatkus Publishers, 1993.

26) A. RANCHHOD, C. GURAU, R. HACKNEY, The Challenge of Cyber-marketing Planning and Implementation $b y$, ,International Journal of Information Technology and Management (IJITM)", vol. 3, nr 2/3/4, 2004.

27) D.L. HOFFMAN, The Revolution Will Not Be Televised: Introduction to the Special Issue on Marketing Science and the Internet, „Marketing Science”, 19 (1), 2000, s. 1-3.

28) Z. BAUMAN, Globalizacja, PIW, Warszawa 1998, s. 95101.

29) N. KLEIN, No Logo, Świat Literacki, Izabelin 2004, s. $21-$ 80 .

30) B. JESSOP, Thatcherism and Flexibility: The White Heat of a Post-Fordist Revolution, [w:] The Politics of Flexibility, red. B. JESSUP, H. KASTENDIEK, K. NIELSEN, O. PEDERSEN, UK: Edward Elgar, Aldershot, 1991, S. $82-105$.

31) D. BELL, Kulturowe sprzeczności kapitalizmu, PWN, Warszawa 1998

32) A. TOFFLER, Szok przysztości, Zysk, Poznań 1998.

33) P. ENGHOLM, The Controversy Between Modernist and Postmodernist Views of Management Science: Is a Synergy Possible?, Internet, Monash University, May 2001.

34) Porównaj: S. WRÓBEL, Wtadza i rozum. Stadia rozwojowe krytycznej teorii spotecznej, Wydawnictwo Uniwersytetu Adama Mickiewicza, Poznań 2002, rozdz. 3-6.

${ }^{35)}$ M. FOUCAULT, Power Knowledge Selected Interviews \& Other Writings, Random House, New York 2000.

36) A. TOFFLER, Zmiana wtadzy, Zysk, Poznań 2003. G. MORGAN, Obrazy organizacji, PWN, Warszawa 1997.

37) P. BOURDIEU, L.J.D. WAQUANT, Zaproszenie do socjologii refleksyjnej, Oficyna Naukowa, Warszawa 2001.

38) Porównaj: Habermas, Rorty, Kotakowski: Stan filozofii wspótczesnej, oprac. J. NIZZNIK, IFiS PAN, Warszawa 1999.

39) Ł. SUŁKOWSKI, Neopozytywistyczna mitologia $w$ nauce o zarzadzaniu, „Organizacja i Kierowanie”, nr 1 (115), 2004

40) G. PEARSON, Why Not Teach Some Marketing Theory?, „International Journal of Management and Decision Making (IJMDM)", vol. 3, nr 1, 2002. 